\title{
Discussion on the Optimization Path of Internal Control in Universities Under the Background of Government Accounting Reform
}

\author{
Dai Yingying ${ }^{1, *}$ \\ ${ }^{1}$ Finance Department, Shandong Jiaotong University, Jinan, Shandong, 250300, China \\ ${ }^{*}$ Corresponding author. Email: daiyingying666@ 163.com
}

\begin{abstract}
According to the research method of combining theory with practice, this paper combines the regulatory requirements after the reform of government accounting system, and studies the path of improving internal control in universities. First of all, under the background of the reform of government accounting system, it analyses its new requirements and significance. Then, the research results of property rights theory and internal control can provide theoretical basis for this study. Finally, combining the characteristics of universities and the current situation of internal control, this paper analyses the optimization path of improving the effectiveness of internal control in universities from three aspects of information system, business control and operation mechanism. Relevant conclusions can help universities to improve the effectiveness of internal control, improve business performance, and ensure national interests.
\end{abstract}

Keywords: internal control, universities, government accounting system

\section{INTRODUCTION}

Since the expansion of college enrolment, China's higher education has developed rapidly and its scale has increased dramatically. At present, universities have begun to compete in the market as independent legal entities, actively raising funds through various means such as education fees, developing school-run enterprises and accepting donations from the society. This kind of transformation also put forward the new higher request to the university's internal control system. Reform of the government accounting system will be implemented in 2019. The functions of internal control system optimization and government accounting reform in administrative institutions are unified in the governance of government accounting information.

Internal control originated in the United States and flourished in the western developed capitalist countries. Even so, there are many corporate scandals caused by internal control problems in developed countries, including many large multinational enterprises. Compared with the capitalist countries, China still has great differences in economy, culture, society, government, enterprise management and other aspects, which will lead to risks different from those of foreign enterprises. It is of special significance for the application and development of internal control of Chinese enterprises to analyse and study the domestic enterprise internal control cases.

In order to optimize internal control, universities should fully implement laws and regulations, school charter, relevant standards and norms, regulatory documents of competent departments and school rules and regulations.
The person in charge should focus on the workflow of key positions, the power restriction mechanism and the supervision and guarantee measures. We will improve post standards, work standards and management systems. The economic and business activities of the school should be regulated continuously to ensure the orderly operation. The school information system should collect all kinds of data in real time. Data should be used for analysis and sharing. In the whole process, the internal control work should be continuously improved and quantified, and complete the scientific balance of power. In order to form closed-loop management, supervision and evaluation should pay attention to each key link. The internal control system can promote the continuous improvement of the school's internal governance level, ensure the legal compliance of the school's economic and business activities, ensure the safe and effective use of the school's capital assets, the authenticity and integrity of financial reports and relevant information, improve work efficiency and effect, and promote the healthy and sustainable development of the school's business.

Under the new situation, the implementation of the new government accounting system, government assets can be fully and accurately calculated and displayed. University governance needs to fully implement performance management, accelerate the establishment of modern financial system, improve the quality of government accounting information, and improve the level of financial and budget management. Therefore, under the background of government accounting reform, the optimization of university internal control is further studied by combining with the theory of internal control. It is of great significance to further promote the reform of higher 
education mechanism, improve the governance structure of institutions of higher learning, and establish the management mode conforming to the modern education system.

\section{REVIEW OF RELATED LITERATURE}

Internal control came into being in the 18th century, until now, it has been perfected to form a whole set of system concepts. Now the more recognized view is that the development of internal control has gone through five stages: internal containment, internal control system, and internal control structure, the whole framework of internal control and enterprise risk management integration framework.

Internal control is the foundation of unit governance and external supervision. In the process of development of Chinese institutions of higher learning, they are faced with the problems of unclear rights and responsibilities and imperfect internal control. After the reform of the government accounting system, this study evaluates the effectiveness of the internal control by virtue of the relevant theories of internal control and combining with the characteristics and status quo of Chinese institutions of higher learning, and puts forward specific suggestions, which is of great significance for standardizing the operation and external supervision of institutions of higher learning.

Zhao (2015) divided the internal control of universities into four basic categories: concept, activity, system and mechanism. On the basis of the above four basic categories to build the internal control framework system. Its frame system is composed of three parts: concept frame, practice frame and information frame. Liu (2013) based on the perspective of financial risk, the university internal control framework system, starting from the present situation of increasing financial risk, universities need to perfect the governance structure, optimize the internal control environment, standardize colleges budget system, perfecting the financial system, perfecting the control activities and strengthen supervision and internal control, in order to build and perfect the internal control framework system in Chinese universities to provide some Suggestions. From the perspective of legal regulation, Zhao hongwei (2016) proposed that universities should set up independent internal audit institutions under the direct leadership of the main responsible person, and explored the ways to construct the dependency between the internal audit regulations of universities and eliminate the misalignment of regulations. Based on the basic framework of COSO system, Chen liuping et al. (2014) constructed the internal control system of universities.

Wang Xiubo (2016) believes that the corporate governance structure has a positive impact on internal control, and it is of great significance for internal control to formulate relevant systems and improve the incentive and constraint mechanisms of corporate managers. Wang Bing et al. (2015) found that the company's internal audit played a positive role in internal control, and the professional skills and management level of the person in charge of internal audit played an important role in improving internal control. Han Zhongxue et al. (2016) obtained the degree of equity balance, shareholding ratio of the board of directors, equity concentration, shareholding ratio of the board of supervisors and shareholding ratio of the management through empirical research, which negatively related to the degree of disclosure of internal control issues. Gan Shengdao et al. (2014) found that the power allocation of the company's management is one of the preconditions to ensure the effectiveness of the company's internal control. To sum up, internal audit and internal accounting control are indispensable in the internal control of universities. Only the scientific establishment of internal control procedures of accounting in universities can effectively improve the effect of internal control. Relevant measures mainly include determination of work procedures, improvement of post responsibilities, monitoring of key posts, authorization and control responsibilities, establishment of pre event and post event supervision system, and improvement of investigation mechanism. This can accelerate the reform and transformation of the management system of universities, improve the internal control of universities, and ensure the healthy development of universities.

\section{COUPLING COORDINATION RELATION}

The government accounting reform and the internal control optimization have a coupling relationship in function. By strengthening the internal control optimization, universities improve the relevant system, process and job responsibilities, strengthen the process control in the generation of accounting information, and ensure the authenticity of accounting information, the safety and integrity of assets, and the reliability of financial reports. The government accounting reform can promote the update and improvement of the internal control system in universities, promote the information analysis of financial accounting and budget accounting, and guide universities to improve the internal control system optimization.

The completion of government accounting reform is inseparable from the optimization of internal control. The standardized unification of government accounting standards and system means that the accounting system previously existed in different administrative institutions has been unified, and information will replace the simple and repetitive accounting activities of accountants. Financial personnel will move from accounting to management accounting, and the content and process of this transition is largely the content and process of internal control optimization. Universities should standardize economic and business activities through internal control, collect business financial data, realize the integration of material flow, data flow and information flow, and ensure the authenticity and integrity of accounting data collection. 


\section{SUMMARY OF OPTIMAL PATH}

Timely information disclosure and transparency can effectively improve the effect of internal control and reduce the disadvantages caused by information asymmetry. The Ministry of Education in the government accounting system implementation opinions main task, put forward to implement the government accounting system as an opportunity to set up "with harmony" concept, effective docking business information systems and financial information system, promote the development of fusion depth of economic business and financial management, building information platform of covering the whole process of economic activities, the implementation of economic business network, platform, intelligent, accounting implementation to provide technical support for the government. Universities should take the opportunity of promoting information construction to further promote the construction of internal control of information system at the unit level, realize the integration and aggregation of material flow, data flow and information flow, ensure the authenticity and integrity of accounting data collection, so that the internal control of information technology can be implemented.

Universities should make use of the preparation work of government accounting system to further improve and optimize the internal control of budget business, asset business, contract business and other business level. Budget management is the core of financial management. Strengthening budget management and establishing a modern financial system are the internal guarantee to promote the reform of government accounting system. In accordance with the new government accounting system, Universities should further clarify the risks and control measures of budget operation, establish and improve the internal management system of budget operation, clarify the responsibilities and authority, and finally establish a whole-process budget performance management mechanism. In accordance with the requirements of the government accounting system, universities should further clarify the subject of liability for the use of assets, improve the monetary fund management system, implement centralized management, and implement the responsibility of the person responsible for the use and custody of assets. Universities should update the existing asset management system and comprehensively improve the quality of data. Universities should improve the centralized management of contracts, establish and perfect the internal management system and information system of contracts, and clarify the recognition of income rights and liabilities, so as to provide a basis for accounting treatment according to the requirements of the new government accounting system.

Universities should further improve the operational mechanisms such as the deliberative decision-making mechanism, the executive mechanism, the supervisory mechanism and the post responsibility mechanism. Improve the implementation mechanism in the aspects of incompatible job separation, centralized management, information technology control, budget control, accounting control and so on. We will strengthen the supervisory functions of departments for discipline inspection, supervision and auditing, and improve the independent supervisory mechanism. According to the accounting system of the new government, work tasks should be sorted out, key positions in economic activities such as budget operations, revenue and expenditure operations, asset management and contract management should be identified, post responsibility system should be implemented and post rotation system should be implemented. The internal control of unit level operation mechanism is promoted and improved under the background of government accounting reform.

\section{CONCLUSION}

The government accounting system after the reform further clarifies the core issues of the internal control of institutions of higher learning, further clarifies the objectives, principles, mechanisms and direction of government supervision, and provides some innovative Suggestions and ideas from the specific system. The effect of internal control is directly related to the healthy development of colleges and universities. In view of the characteristics of institutions of higher learning, this paper combines the research results on the effectiveness of internal control in institutions of higher learning, which reflects the applicability of combining theory with practice, provides corresponding basis for external supervision of institutions of higher learning in the future, and points out the direction.

Universities should take the implementation of government accounting reform as an opportunity, update and adjust the relevant management system in time according to the provisions of government accounting standards and the new system, and revise and improve the problems found in the process of internal control construction in combination with the actual requirements of internal control norms, so as to ensure the smooth realization of the overall goal of internal control construction.

\section{REFERENCES}

[1] Dragomir Dimitrijevic. The Role of A Company's Internal Control System in Fraud Prevention. E-Finance, 2016, pp. 34-44

[2] Mary Jane Lenard. Internal Control Weaknesses and Evidence of Real Activities Manipulation. Advances in Accounting, incorporating Advances in International Accounting, 2016

[3] Yi Cheng Feng. Internal Research on Internal Control Evaluation for Coal Mine Production Logistics Based on Management Entropy. Advanced Materials Research, 2014, pp. 172-178 
[4] Ioan Gabriel Popa. Evaluation of the Internal Management Control System - Major Objective in the Preparation and Achievement of the Public Internal Audit. International conference KNOWLEDGEBASED ORGANIZATION, 2016, pp.220-226.

[4] Cheng Zhifen, Liao Hua. Strengthening the construction of internal control system and preventing the risk of bill management in universities. Finance and accounting study, 2020, pp.36-37.

[5] Wang Haini. Research on performance evaluation of internal control management of scientific research funds in universities. Friends of accounting, 2020, pp.93-98.

[6] Chen Qun. Research on financial internal control of universities under government accounting system. Commercial accounting, 2019, pp.106-108.

[7] Hao Juling, Li Liguang. Research and analysis on the internal audit work of universities under the accounting system of the new government. China township enterprise accounting, 2019, pp.198-199.

[8] Xu Li. Research on the construction and optimization of internal control in universities under the background of government accounting reform. Tax payment, 2019, pp.56-57.

[9] Liu Guoping,Tang Dapeng. Framework design of internal control system construction in universities directly under the ministry of education. Journal of finance and accounting, 2019, pp.114-117.

[10] Sailor. Analysis on the impact of government accounting reform on the construction of internal control in universities. Modern economic information, 2019, pp.180+183.

[11] Duan Shu, Chen huandi, wang yongfang. Reflections on the construction of internal control environment in public universities from the perspective of contingency theory. Finance and accounting, 2019, pp. 73-74.

[12] Zhao Meirong. Discussion on internal audit strategy in universities from the perspective of government accounting. Finance and accounting, 2019, pp.75-76.

[13]Yang Congyin, Liu Xiaohua. Current situation, difficulties and countermeasures of internal control construction in universities -- analysis based on selfevaluation report of internal control construction in universities. Journal of finance and accounting, 2019, pp.122-125.

[14] Zhao Hongwei. Basic category and framework construction of internal control in institutions of higher learning. Audit research, 2015, pp. 108-112.

[15] Zhao Hongwei. Modern university system and internal audit of institutions of higher learning. China internal audit, 2014, pp. 20-22.

[16] Chen Liuping, Wei wei, Zhang Yanchao. On the construction of internal control in Chinese universities - a survey based on jiangsu universities. College education management, 2014, pp.29-35. 